Zeszyty Naukowe Szkoły Głównej Gospodarstwa Wiejskiego

Ekonomika i Organizacja Gospodarki Żywnościowej nr 110, 2015: 19-32

Ryszard Kata

Wydział Ekonomii

Uniwersytet Rzeszowski

\title{
Procesy integracji i konsolidacji spółdzielczego sektora bankowego w Polsce
}

\section{Wstęp}

Sektor bankowości spółdzielczej (SBS) w Polsce od wielu lat podlega nieustannemu procesowi przekształceń i dostosowań. Na początku lat 90. były to dostosowania do warunków gospodarki rynkowej, w kolejnych latach zaś przekształcenia determinowane przez rosnącą konkurencję i postępujące procesy koncentracji $\mathrm{w}$ sektorze bankowym oraz sytuację $\mathrm{w}$ otoczeniu makroekonomicznym. Ważnym czynnikiem zmian były także regulacje prawne bankowości dotyczące m.in. minimalnego poziomu kapitałów własnych banków. Wymienione uwarunkowania skutkowały procesami konsolidacji banków spółdzielczych (BS) oraz konsolidacji i integracji całego sektora.

Nowe regulacje dotyczące bankowości są zwykle pochodną określonych problemów w systemie finansowym i jego subsystemie bankowym. $Z$ takimi problemami, w skali systemu finansowego na świecie, mieliśmy do czynienia pod koniec ubiegłego stulecia i w początkowych latach obecnego wieku [Roubini, Mihm 2011]. Ich efektem był kryzys finansowy lat 2007-2008, z jego dalszymi skutkami dla całej gospodarki światowej oraz systemów finansów publicznych krajów rozwiniętych, w tym Unii Europejskiej. Odpowiedzią na te problemy są opracowane przez Komitet Bazylejski propozycje zmian regulacyjnych w sektorze bankowym (tzw. Bazylea III), które w UE znalazły swój wyraz w postaci dyrektywy CRD IV i rozporządzenia CRR ${ }^{1}$. Ich konsekwencje dotykać

\footnotetext{
${ }^{1}$ Dyrektywa PE i Rady 2013/36/UE z dnia 26 czerwca 2013 roku w sprawie warunków dopuszczenia instytucji kredytowych do działalności oraz nadzoru ostrożnościowego nad instytucjami kredytowymi i firmami inwestycyjnymi (Capital Requirements Directive IV, CRD IV) oraz Rozporządzenie PE i Rady nr 575/2013 z dnia 26 czerwca 2013 roku w sprawie wymogów ostrożnościowych dla instytucji kredytowych i firm inwestycyjnych (Capital Requirements Regulation, CRR).
} 
będą bankowość lokalną w UE i w Polsce, na równych zasadach jak duże banki komercyjne i konglomeraty finansowe, co wynika z niedostatecznego uwzględniania zasady proporcjonalności w implementacji unijnych regulacji bankowych [Bańka 2013, s. 7] $]^{2}$.

Wprowadzenie pakietu CRD IV/CRR do europejskiego porządku prawnego (z dniem 1 stycznia 2014 r.) stawia przed bankowością spółdzielczą nowe wyzwania. Innym źródłem wyzwań dla sektora są zmiany, jakie mają miejsce na rynku finansowym oraz obserwowane w ostatnich latach pogarszanie się efektywności ekonomicznej SBS w Polsce. Wszystkie te okoliczności powodują konieczność dalszych przekształceń sektora bankowości spółdzielczej, w których kluczową rolę będą odgrywały procesy konsolidacyjne i integracyjne.

\section{Cel i metodyka badań}

Celem opracowania jest określenie istoty i skali procesów konsolidacyjnych i integracyjnych, jakie miały miejsce w bankowości spółdzielczej w Polsce w latach 1993-2013 oraz identyfikacja przesłanek determinujących konieczność dalszych przekształceń spółdzielczego sektora bankowego oraz określenie roli i charakteru procesów konsolidacyjnych i integracyjnych w kształtowaniu nowego modelu organizacyjno-biznesowego bankowości spółdzielczej w Polsce.

Źródłem materiałów empirycznych do badań były statystyki sektora bankowego publikowane przez Komisję Nadzoru Finansowego (KNF) i Narodowy Bank Polski (NBP). Dokonano także przeglądu literatury przedmiotu oraz wykorzystano raporty i opracowania Związku Banków Polskich (ZBP).

\section{Wyniki badań i ich omówienie}

W bankowości spółdzielczej w Polsce w latach 1993-2013 mogliśmy obserwować jednocześnie przebiegające procesy, które wpłynęły na obecny kształt tego sektora bankowego. Te procesy to:

1) Integracja organizacyjna sektora, sprowadzająca się do utworzenia najpierw trójszczeblowej, a następnie dwuszczeblowej struktury organizacyjnej. Integracja sektora przejawiała się także w przyjmowaniu podobnych rozwiązań informatycznych czy wspólnych działaniach marketingowych;

2) Konsolidacja obejmujące banki spółdzielcze oraz banki zrzeszające (BZ).

\footnotetext{
${ }^{2}$ Zasada ta wskazuje, iż wszystkie standardy i wymogi powinny być stosowane przez objęte nimi instytucje w sposób proporcjonalny do charakteru, skali i stopnia złożoności tych instytucji.
} 
Pojęcie konsolidacji jest różnorodnie rozumiane ze względu na złożoność tego procesu, ponadto czym innym będzie konsolidacja banków, a czym innym konsolidacja sektora bankowego. Słowo konsolidacja pochodzi od łacińskiego consolidatio - spojenie. Stownik wspótczesnego języka polskiego podaje następujące rozumienie tego słowa: „zjednoczenie, zespolenie, połączenie $\mathrm{w}$ jedną całość, umocnienie, utrwalenie, ugruntowanie" [Dunaj 1996, s. 407]. W biznesie konsolidacja oznacza połączenie podmiotów przez zjednoczenie, w wyniku którego łączące się podmioty tracą osobowość prawną, a zamiast nich powstaje nowe przedsiębiorstwo [Frąckowiak 2009].

Głównymi przyczynami procesów konsolidacyjnych w bankowości są:

- zmiany regulacji prawnych dotyczących sektora bankowego,

- zmiany makrootoczenia ekonomicznego, w tym koniunktury na rynku finansowym i w gospodarce,

- korzyści wynikające ze skali i zakresu prowadzonej działalności,

- innowacje technologiczne [Sablik 2004, s. 133].

Łączenie się banków pozwala na osiagnnięcie takich celów, jak: rozszerzenie asortymentu oferowanych produktów, zmniejszenie kosztów stałych, zwiększenie liczby posiadanych placówek (co z kolei prowadzi do zwiększenia ilości klientów i obrotów banku), skoncentrowanie funduszy własnych łączących się jednostek czy poprawienie jakości portfela kredytowego [Kraciuk 2006, s. 282].

Z kolei do najważniejszych celów konsolidacji grup bankowych należą: redukcja kosztów operacyjnych, zwiększenie efektywności i sprawności kierowania całą grupą oraz poprawa pozycji rynkowej grupy banków [Kozak 2013, s. 35].

Integracja jest pojęciem czasami utożsamianym z konsolidacją, jest to jednak działanie prowadzone w celu uzyskania wewnętrznej (większej) spójności jakiejś grupy lub struktury i jej umocnienia. Zatem różnica polega na tym, iż w efekcie konsolidacji (fuzji, przejęcia) powstaje nowa (z reguły większa) organizacja. Natomiast integracja polega na zmianach wewnątrz tej samej organizacji, a także na procesach silniejszego współdziałania odrębnych, autonomicznych podmiotów, które to współdziałanie prowadzi do większej spójności wewnątrz struktury już istniejącej lub do powstania nowej struktury, dalej jednak składającej się z niezależnych podmiotów. Przykładem integracji w bankowości jest tworzenie zrzeszeń w bankowości spółdzielczej, skupiających niezależne banki spółdzielcze oraz banki zrzeszające, pełniące wobec nich funkcje usługowe i kontrolne.

Integracja może mieć zróżnicowaną siłę, tj. od słabej (tworząc struktury organizacyjne o relatywnie luźnych powiązaniach poziomych i pionowych), po silną, prowadzącą do tworzenia zintegrowanych grup bankowych, w ramach których banki lokalne zachowują ograniczoną niezależność. 
Na rysunku 1 przedstawiono skalę procesów konsolidacji banków spółdzielczych, jakie miały miejsce w Polsce w latach 1993-2013. Na początku tego okresu funkcjonowały 1663 BS, a dwie dekady później już tylko $571 \mathrm{BS}$, z czego 206 było zrzeszonych w SGB-Banku SA w Poznaniu, a 364 w Banku Polskiej Spółdzielczości (BPS SA) w Warszawie (1 BS działa poza zrzeszeniem). W latach 1994-1997 procesy konsolidacyjne miały głównie charakter sanacyjny, gdy silniejsze banki spółdzielcze (sporadycznie także komercyjne) ${ }^{3}$, wspierane środkami pomocowymi z instytucji nadzorczych, przejmowały BS zagrożone upadłością [Kozak 2013, s. 26, Rosa 2012, s. 834]. W kolejnych latach głównym determinantem procesów konsolidacyjnych były już regulacje prawne związane z implementacją unijnej dyrektywy bankowej z 1989 roku (89/229/EEC L124) dotyczącej funduszy własnych banków, co było elementem dostosowania Polski do stanu prawnego UE. Konieczność osiagnięcia kapitałów własnych przez bank spółdzielczy na poziomie $1 \mathrm{mln}$ euro (do końca 2007 r.), a w przypadku banku zrzeszającego na poziomie $20 \mathrm{mln}$ euro (do końca 2006 r.) zapisano w ustawie z 7 grudnia 2000 roku o funkcjonowaniu banków spółdzielczych, ich zrzeszaniu się i bankach zrzeszających (Dz.U. z 2000 r. nr 119, poz. 1252). Ustawa ta przyczyniła się także do przekształcenia trójszczeblowej struktury organizacyjnej SBS ${ }^{4}$ w nową dwuszczeblową strukturę, składającą się z banków spółdzielczych oraz banków regionalnych i zrzeszających.

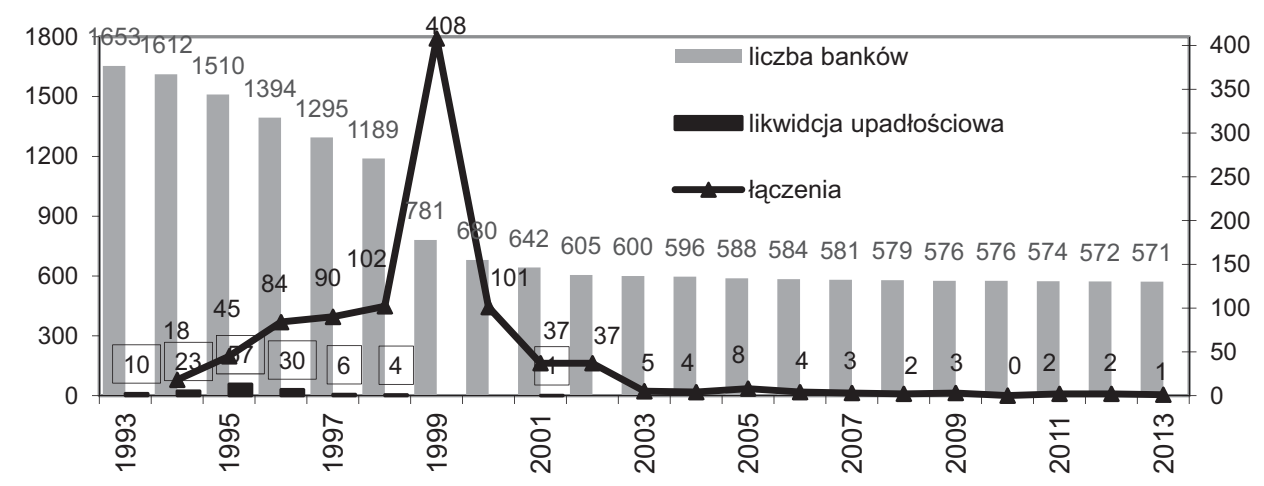

Rysunek 1

Liczba BS oraz ich procesów konsolidacji i upadłości w latach 1993-2013

Źródło: Dane NBP i KNF za lata 1993-2013.

\footnotetext{
${ }^{3}$ Łącznie 30 BS zostało przejętych w procesie likwidacji upadłościowej przez banki komercyjne.

${ }^{4}$ Funkcjonującą od 1994 roku strukturę tworzyły BS, banki regionalne oraz BGŻ SA jako bank krajowy.
} 
Kolejny etap reorganizacji sektora BS to łączenia banków zrzeszających i regionalnych. Zbyt duża liczba tych banków generowała wysokie koszty, ponadto błędy w zarządzaniu i ładzie korporacyjnym powodowały, iż koniec lat 90. ich sytuacja ekonomiczna mocno się pogorszyła. Te problemy, a także wspomniane wymogi kapitałowe narzucone bankom zrzeszającym, były przyczyną konsolidacji zrzeszeń. W efekcie w latach 2000-2001 z 11 zrzeszeń powstały 3, tworzone przez BPS SA, Gospodarczy Bank Wielkopolski (GBW SA) i Mazowiecki Bank Regionalny SA. W roku 2011 nastapił kolejny etap konsolidacji, tj. połączenie MR Banku SA z GBW SA i utworzenie zrzeszenia Spółdzielcza Grupa Bankowa (GBW SA. zmienił też nazwę na SGB Bank SA).

Bardzo dynamiczny wzrost podstawowych wielkości bilansowych, osiągnięty przez banki spółdzielcze w latach 1994-2013, nie byłby możliwy bez procesów konsolidacyjnych w sektorze (rys. 2). W okresie tym aktywa BS wzrosły realnie o $307 \%$, należności i zobowiązania klientów niefinansowych wzrosły odpowiednio o 453 i $412 \%$, kapitały własne powiększyły się zaś o $1880 \%$. Pomimo tak spektakularnej dynamiki wzrostu, udział spółdzielczego sektora bankowego w wielkościach bilansowych systemu bankowego w Polsce powiększał się znacznie wolniej (tab. 1). Zważywszy natomiast na udział SBS w liczbie placówek bankowych w kraju $(31,5 \%)$ oraz zatrudnieniu $(20,2 \%)$, możemy mówić o niewykorzystanym potencjale dystrybucyjnym oraz ekonomicznym i społecznym sektora.

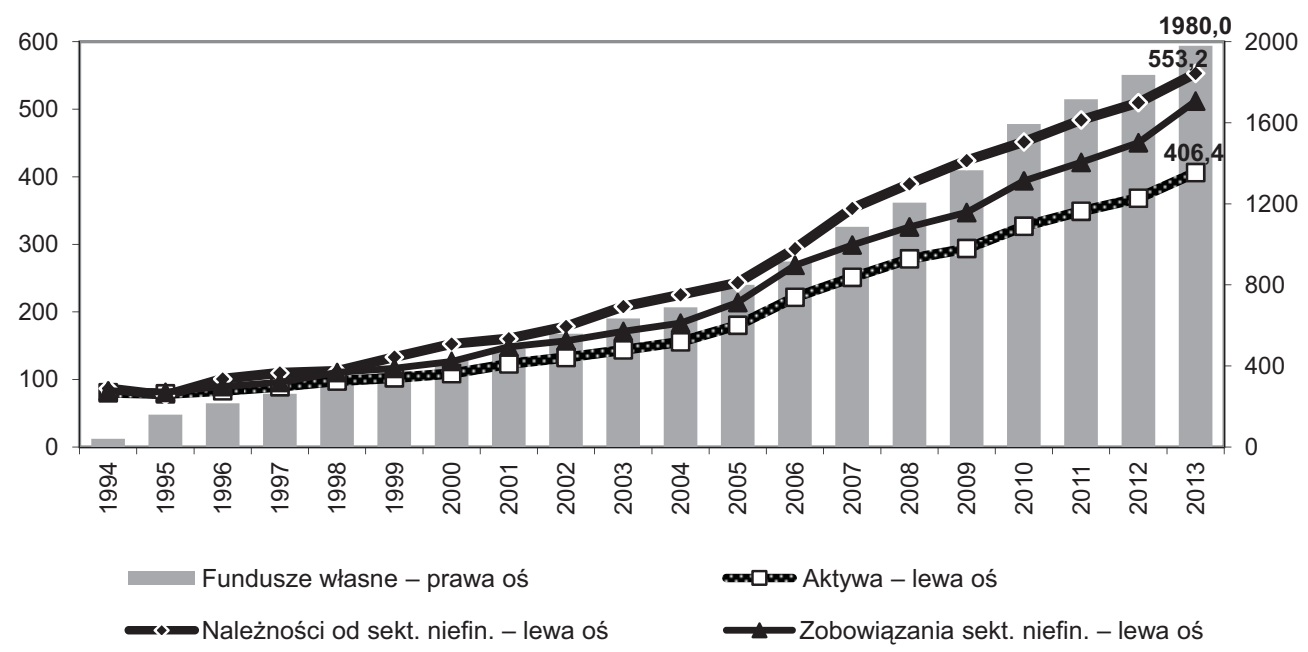

Rysunek 2

Dynamika podstawowych wielkości bilansowych BS w latach 1993-2013 w ujęciu realnym (rok $1993=100 \%)$

Źródło: Obliczenia własne na podstawie danych NBP i KNF za lata 1993-2013. 
Tabela 1

Udział sektora bankowości spółdzielczej (łącznie BS i BZ) w sektorze bankowym [\%]

\begin{tabular}{|l|c|c|c|c|c|c|c|}
\hline Wyszczególnienie & 1994 & 2004 & 2008 & 2010 & 2011 & 2012 & 2013 \\
\hline Aktywa & 5,5 & 7,2 & 7,3 & 8,3 & 8,2 & 8.6 & 9,2 \\
\hline Fundusze własne & 1,2 & 6,5 & 7,7 & 8,0 & 8,2 & 8,2 & 8,1 \\
\hline Kredyty dla sektora niefinansowego & 6,2 & 8,8 & 6,3 & 7,2 & 7,1 & 7,7 & 7,8 \\
\hline Depozyty sektora niefinansowego & 5,9 & 9,4 & 8,8 & 9,0 & 8,9 & 9,4 & 10,1 \\
\hline Zatrudnienie & 18,0 & 18,9 & 18,7 & 19,3 & 19,8 & 20,0 & 20,2 \\
\hline
\end{tabular}

Źródło: Statystyki NBP i KNF za lata 1994-2013.

Procesy konsolidacji oprócz korzyści moga przynieść podmiotom w nich uczestniczącym wiele trudności i zagrożeń. Połączone banki to nowe podmioty, które muszą sprostać ryzyku operacyjnemu w nowym nieznanym im dotąd wymiarze. Zmienia się obszar działania, komplikuje się struktura zarządzania, wzrasta skala działalności, a częstokroć - w konsekwencji połączenia -zmienia się technologia informatyczna i pojawiają się dodatkowe koszty. Badania Mielnika i Szambelańczyka [2006] prowadzone w latach 1997-2003 wskazują, iż w większości przypadków banki, które uczestniczyły w procesach konsolidacyjnych (przejmujące) wykazywały niższą efektywność (mierzoną metodąDEA) w porównaniu do banków, które w takich procesach nieuczestniczyły. Badania te były jednak prowadzone w niewielkim odstępie czasu po zakończeniu procesów łączeniowych. Tymczasem jak wiadomo pewne koszty i niekorzyści konsolidacji ujawniają się relatywnie szybko (w okresie łączeń i bezpośrednio po nich), korzyści są natomiast rozłożone w czasie i występuje efekt przesunięcia.

Tabela 2

Wyniki ekonomiczne BS o największych i najmniejszych aktywach (lata 2010-2013)

\begin{tabular}{|l|c|c|c|}
\hline \multirow{2}{*}{ Wyszczególnienie } & \multirow{2}{*}{ j.m. } & \multicolumn{2}{|c|}{ Banki o sumie aktywów (A) } \\
\cline { 3 - 4 } & & $\begin{array}{c}\text { A }<100 \mathrm{mln} \text { zł } \\
(\mathrm{n}=267)\end{array}$ & $\begin{array}{c}\mathrm{A} \geq 500 \mathrm{mln} \text { zł } \\
(\mathrm{n}=34)\end{array}$ \\
\hline 1. Należności od sektora niefinansowego & & & \\
a) wzrost nominalny w latach 2010-2013 & $\%$ & 21,8 & 52,9 \\
$\quad$ - średnie tempo przyrostu rocznie & $\%$ & 6,8 & 15,2 \\
b) przeciętny udział w strukturze aktywów & $\%$ & 49,5 & 61,1 \\
\hline 2. Zobowiązania wobec sektora niefinansowego & $\%$ & 31,8 & 58,7 \\
- wzrost nominalny w latach 2010-2013 & $\%$ & 9,6 & 16,6 \\
$\quad$ - średnie tempo przyrostu rocznie & $\%$ & 71,0 & 65,9 \\
\hline 3. Przeciętny poziom wskaźnika C/l & $\%$ & 1857 & 3292 \\
\hline 4. Przeciętny poziom aktywów na zatrudnionego & tys. zł & 10,4 & 20,1 \\
\hline - wzrost w latach 2010-2013 & $\%$ & 35,5 & 28,2 \\
\hline 5. Wynik finansowy brutto na zatrudnionego & tys. zł & 3
\end{tabular}

Źródło: Obliczenia własne na podstawie [KNF 2014]. 
Korzyści z konsolidacji BS są widoczne, jeśli porównamy w ostatnich latach tempo wzrostu i wyniki finansowe banków o największych aktywach w sektorze (powyżej $500 \mathrm{mln}$ zł) oraz banków o aktywach poniżej $100 \mathrm{mln}$ zł (tab. 2). Do tej pierwszej grupy należą banki, które bardzo aktywnie uczestniczyły w procesach konsolidacyjnych, przyłączając najczęściej po kilka mniejszych BS. $\mathrm{Z}$ kolei $\mathrm{w}$ drugiej grupie przeważają banki, które nie brały udziału w procesach konsolidacyjnych. W przypadku pierwszej grupy obserwujemy w latach 2010 -2013 znacznie szybszą dynamikę wzrostu należności i zobowiązań sektora niefinansowego oraz wyższą efektywność ekonomiczną (tab. 2). Pozytywne efekty konsolidacji, m.in. w zakresie poprawy stabilności finansowej oraz pozycji banków na rynku finansowym, potwierdzają także sami uczestnicy tych procesów. W większości wskazują jednak, iż gdyby nie wymogi regulacyjne (progi kapitałowe), to banki dobrowolnie by się nie łączyły, lecz starałyby się utrzymać samodzielność 5 .

Luka między potencjałem dystrybucyjnym SBS a jego udziałem w systemie bankowym jest rezultatem niższej efektywności ekonomicznej BS w porównaniu do banków komercyjnych (BK), mierzonej wielkością aktywów, kapitałów czy przychodów z działalności bankowej w relacji na zatrudnionego. Przekłada się to także na niższe wskaźniki zyskowności i efektywności działania BS, które zwłaszcza w ostatnich latach (2012-2013) uległy pogorszeniu (tab. 3).

Problemy ekonomiczne sektora BS można ująć w następujących punktach:

1) Kurcząca się „,bezpieczna przestrzeń dochodowa” BS, której symptomem jest znaczący spadek marży odsetkowej i zawężenie spreadu między BS i BK (do 0,9 p.p.) oraz wysokie i rosnące koszty działania BS (tab. 3).

2) Obniżająca się sukcesywnie rentowność aktywów oraz kapitałów własnych. Spadek jest szybszy i do poziomu niższego niż w sektorze BK (tab. 3).

3) Postępujące rozwarstwienie - małe banki rozwijają się znacznie wolniej niż duże BS (tab. 2), co utrudnia wprowadzanie jednakowych (w zrzeszeniu) rozwiązań produktowych, organizacyjnych czy informatycznych.

4) Pogorszenie wyników ekonomicznych banków zrzeszających ${ }^{6}$.

5) Duże nadwyżki środków płynnych (w 2013 r. relacja kredytów do depozytów sektora niefinansowego wynosiła $69,4 \%$ ) wskazujące na niewystarczająca aktywność BS na lokalnych rynkach kredytowych oraz brak zorganizowanego mechanizmu dystrybucji i transformacji depozytów w kredyty wewnątrz zrzeszeń.

\footnotetext{
${ }^{5}$ Takiej odpowiedzi udzieliło w badaniach ankietowych 65\% BS uczestniczących w procesach konsolidacji i aż 94\% BS utrzymujących samodzielność [Kot-Zacharuk 2011, s. 271-272].

${ }^{6} \mathrm{~W} 2013$ roku banki te znacząco zwiększyły rezerwy na należności zagrożone (w przypadku BPS SA z 14,3 do 23,5\%). BPS odnotował 153,7 mln zł straty netto (w 2012 r. - $17 \mathrm{mln}$ zł).
} 
6) Wzrost ryzyka działalności kredytowej spowodowany ekspansją BS na rynek miejski oraz wzrostem udziału przedsiębiorstw w ich portfelu kredytowym. W efekcie odsetek kredytów zagrożonych rośnie w BS szybciej niż w BK (tab. 3).

7) Ograniczone inwestycje w rozwój, w tym w nowoczesne technologie informatyczne (w 2013 r. nakłady na wartości niematerialne i prawne w BS w relacji na zatrudnionego stanowiły zaledwie $11 \%$ takich nakładów w BK).

8) Ograniczony popyt na kredyty w tradycyjnym środowisku działania BS.

9) Konkurencja wewnątrz spółdzielczego sektora bankowego (między BS i między zrzeszeniami), co osłabia spójność sektora i jego pozycję konkurencyjną.

Część problemów sektora wynika $\mathrm{z}$ niepełnego wykorzystania funkcji banków zrzeszających jako integratorów zrzeszenia, a częściowo jako back office banków lokalnych. Przy istniejącym modelu działania zrzeszeń, bez budowania silniejszych powiązań biznesowych, generowane są pewne ryzyka [Pruski 2012, s. 6-9]. Duże uzależnienie wyników BS od banków zrzeszających (ze względu na blisko $30 \%$ udział lokat w banku zrzeszającym w aktywach BS) powoduje obniżenie się efektywności

\section{Tabela 3}

Znamiona pogarszania się sytuacji ekonomicznej BS na tle banków komercyjnych

\begin{tabular}{|l|c|c|c|}
\hline Wyszczególnienie & j.m. & BS & BK \\
\hline 1. Zmiana marży odsetkowej w latach 2004-2013 & p.p. & $-2,2$ & $-0,3$ \\
\hline 2. Zmiana C/I 2013/2012 & p.p. & $+5,0$ & $+2,0$ \\
\hline 3. Zmiana ROA: 2013/2004 & p.p. & $-1,0$ & $-0,3$ \\
$2013 / 2012$ & & $-0,3$ & $-0,1$ \\
\hline 2013/2012 & p.p. & $-10,4$ & $-6,9$ \\
$-3,3$ & $-1,0$ \\
\hline 4. Zmiana ROE: 2013/2004 & & $-3,3$ \\
\hline 5. Zmiana wsk. kredytów zagrożonych 2013/2008 & p.p. & $+3,6$ & $+3,5$ \\
- wzrost w stosunku do poziomu z 2008 roku & $\%$ & 128,5 & 67,3 \\
\hline 6. Nakłady na wartości niemat. i prawne na zatrud. (2013) & tys. zł & 0,8 & 7,3 \\
\hline 7. Wynik z działalności bankowej na zatrudnionego (2013) & tys. zł & 128,1 & 326,9 \\
\hline 8. Zmiana wynik finansowego netto 2013/2012 & $\%$ & $-21,8$ & $+1,2$ \\
\hline 9. Zmiana zatrudnienia 2013/1999 & $\%$ & $+31,9$ & $-5,6$ \\
\hline 10. Aktywa na zatrudnionego w 2013 roku & mln zł & 2,9 & 9,3 \\
\hline 11. Zysk netto na zatrudnionego [w tys. zł] & tys. zł & 22,7 & 103,2 \\
- zmiana 2013/2012 [\%] & $\%$ & $-22,5$ & $+1,1$ \\
\hline 12. Kredyty/depozyty (2013) & $\%$ & 68,1 & 107,6 \\
\hline 13. Należności od sektora finansowego/ aktywa & $\%$ & 29,4 & 6,3 \\
\hline 14. Udział przedsiębiorstw w portfelu kredytowym (2013) & $\begin{array}{c}\% \\
\text { - zmiana 2013/2010 }\end{array}$ & $\begin{array}{c}31,7 \\
+7,1\end{array}$ & $\begin{array}{c}32,5 \\
+0,2\end{array}$ \\
\hline
\end{tabular}

Źródło: Obliczenia własne na podstawie [KNF 2014]. 
działania zarówno BS, jak i BZ. Banki zrzeszające nie są w stanie uzyskać wysokiej marży odsetkowej i efektywności działania ze względu na: wysokie koszty pasywów od BS; ograniczoną sieć dystrybucji oraz konieczność utrzymywania płynności dla banków spółdzielczych. Aby pokryć koszty zobowiązań wobec BS, zmuszone są angażować się w ryzykowne obszary działalności.

Wymienione wyżej problemy ekonomiczne sektora bankowości spółdzielczej wiążą się z koniecznością zmiany modelu biznesowego [Pruski 2013, s. 12]. Dotyczy to zarówno banków spółdzielczych, które zmuszone są do poszukiwania nowych obszarów aktywności i źródeł przychodów, jak i całego sektora, a ściślej funkcjonujących dwu zrzeszeń stojących przed koniecznością silniejszej integracji BS z bankami zrzeszającymi. Poprawa efektywności finansowej zrzeszeń wymaga:

- efektywnego zagospodarowania nadwyżek środków pieniężnych z działalności depozytowej BS poprzez ich transfer wewnątrz zrzeszenia i wspólne inwestycje,

- integracji oferty produktowej, sfery informatycznej (ujednolicenie systemów, wspólne inwestycje w sferze IT) oraz sieci dystrybucyjnej,

- ujednolicenia metod i systemów zarządzania ryzykiem wewnątrz zrzeszenia,

- konsolidacji w zakresie zarządzania płynnością w obrębie grupy (zrzeszenia).

Tak jak wspomniano wcześniej, obok wyzwań o charakterze ekonomicznym, duży wpływ na dalsze przekształcenia i rozwój spółdzielczego sektora bankowego będą miały unijne regulacje prawne. Dotyczą one przede wszystkim implementacji nowych wymogów kapitałowych i płynnościowych dla banków określonych w pakiecie CRD IV/CRR oraz regulacjach tworzących nową architekturę systemu bankowego w UE, określaną jako unia bankowa (tab. 4).

Sprostanie tym wymogom i ryzyku regulacyjnemu, które z nich wynika (tab. 4), wiąże się ze zmianami instytucjonalnymi w ramach sektora BS, zwiększającymi zakres współdziałania (integracji), na niektórych obszarach (płynność finansowa) konsolidacji między bankami wewnątrz zrzeszeń. W pierwszej kolejności chodzi o wypełnienie normy płynności krótkoterminowej LCR (od początku 2015 r.), która zobowiązuje banki do utrzymywania wysokiej jakości aktywów płynnych ${ }^{7}$. Banki mogą tę normę wypełnić samodzielnie, co będzie bardzo trudne dla wielu z nich, albo stworzyć „,grupę płynnościową”, która zwolni je z obowiązku utrzymania wskaźnika LCR na poziomie indywidualnym, z jedno-

\footnotetext{
${ }^{7}$ LCR - relacja aktywów płynnych do wypływów netto, określa „,horyzont przeżycia”, czyli posiadany zapas aktywów płynnych oraz wysokiej jakości należności, który ma pozwolić na pokrycie przewidywanego odpływu środków w sytuacji kryzysowej w ciągu 30 dni.
} 
Tabela 4

Wyzwania dla bankowości spółdzielczej wynikające z nowych regulacji UE

\begin{tabular}{|c|c|}
\hline Regulacje/Wymogi & Problemy i zagrożenia dla SBS - ryzyko regulacyjne \\
\hline \multicolumn{2}{|r|}{ Pakiet CRD IV/CRR } \\
\hline $\begin{array}{l}\text { Podwyższone wymogi w za- } \\
\text { kresie jakości kapitałów wła- } \\
\text { snych banków }\end{array}$ & $\begin{array}{l}\text { - Brak zaliczenia funduszu udziałowego (w obecnej jego formie } \\
\text { prawnej) do kapitału Tier I oraz pożyczek podporządkowanych } \\
\text { do kapitału Tier II }\end{array}$ \\
\hline $\begin{array}{l}\text { Norma płynności krótkotermi- } \\
\text { nowej LCR (Liquidity Covera- } \\
\text { ge Ratio - CRR, art. 412). Ma } \\
\text { być wprowadzana stopniowo } \\
\text { od } 2015 \mathrm{r} \text {. }\end{array}$ & $\begin{array}{l}\text { - Zaliczanie do funduszy niestabilnych środków gromadzonych } \\
\text { przez jednostki samorządu terytorialnego } \\
\text { - W bankach zrzeszających środki BS nie będa traktowane } \\
\text { jako źródła stabilnego finansowania. BZ nie będzie mógł nimi } \\
\text { finansować działalności kredytowej }\end{array}$ \\
\hline $\begin{array}{l}\text { Norma płynności długotermi- } \\
\text { nowej NSFR (Net Stable Fun- } \\
\text { ding Ratio - CRR, art. } 413 \text {, } \\
\text { pkt 3). Ma obowiązywać naj- } \\
\text { wcześniej od } 2018 \text { r. }\end{array}$ & $\begin{array}{l}\text { - Niedopasowanie bilansu banków w aspekcie terminów zapa- } \\
\text { dalności aktywów i wymagalności pasywów (na koniec } 2013 \text { r. } \\
\text { aktywa długoterminowe stanowiły } 56,4 \% \text { sumy bilansowej, } \\
\text { a zobowiazania długoterminowe tylko } 14,4 \% \text { ) } \\
\text { - Pozyskanie aktywów długoterminowych = wyższe koszty } \\
\text { działalności bankowej i dalsza redukcja marży odsetkowej }\end{array}$ \\
\hline \multicolumn{2}{|c|}{ Regulacje resolution regime w ramach unii bankowej* } \\
\hline $\begin{array}{l}\text { Prowadzenie działań napraw- } \\
\text { czych oraz restrukturyzacji } \\
\text { i uporządkowanej likwidacji } \\
\text { banków }\end{array}$ & $\begin{array}{l}\text { - Ryzyko wynikające ze zmian odnośnie objęcia banków re- } \\
\text { strukturyzacją i uporządkowaną likwidacja } \\
\text { - Składka na fundusz stabilizacyjny oraz dodatkowe obowiązki } \\
\text { sprawozdawcze = wzrost kosztów działalności }\end{array}$ \\
\hline \multicolumn{2}{|c|}{ Regulacje z zakresu nadzoru makroostrożnościowego } \\
\hline $\begin{array}{l}\text { Wymogi } \\
\text { potrzeby Rady Ryzyka Syste- } \\
\text { mowego. } \\
\text { Możliwość wprowadzania } \\
\text { ostrzejszych norm ostrożno- } \\
\text { ściowych }\end{array}$ & $\begin{array}{l}\text { - Wzrost kosztów działania - dodatkowe nakłady pracy, ko- } \\
\text { nieczność rozbudowy systemów informatycznych } \\
\text { - Wpływ przepisów na strukturę bilansu banków (wymogi płyn- } \\
\text { ności, limity koncentracji zaangażowań, wagi ryzyka, dodat- } \\
\text { kowe bufory kapitałowe), co może zmniejszać dochodowość } \\
\text { banków }\end{array}$ \\
\hline
\end{tabular}

* Dyrektywa PE i Rady 2014/59/UE z dnia 15 maja 2014 roku. Dyrektywa ma objąć bezpośrednio kraje strefy euro, jednak pośrednio będzie implikować zmiany w prawie bankowym wszystkich członków UE.

Źródło: Opracowanie własne.

czesnym obowiązkiem jego spełnienia na poziomie skonsolidowanym. W dalszej kolejności chodzi także o wypełnienie innych norm regulacyjnych (m.in. normy płynności długoterminowej $\mathrm{NSFR}^{8}$ oraz wymogów kapitałowych). Niemniej podkreśla się, iż zmiana modelu biznesowego bankowości spółdzielczej

\footnotetext{
${ }^{8}$ NSFR - relacja funduszy własnych i środków obcych stabilnych (np. długoterminowe lokaty) do aktywów niepłynnych i o ograniczonej płynności, obliczany przy założeniu sytuacji kryzysowej. NSFR ma zapewnić płynność banku w horyzoncie powyżej 1 roku.
} 
nie powinna być realizowana jedynie pod dyktando nowych regulacji bankowych, lecz to wybór odpowiedniej strategii biznesowej powinien determinować model zarządzania płynnością [Pruski 2013].

Dalsze przekształcenia sektora mogą przybrać różną postać, w zależności od formy i siły procesów integracyjnych i konsolidacyjnych wewnątrz poszczególnych zrzeszeń (rys. 1). Pełna konsolidacja finansowa oraz wariant samodzielnego działania dużych BS wydają się najmniej prawdopodobne. W pierwszym przypadku nie ma na to zgody banków spółdzielczych, które podkreślają, iż ich atutem jest niezależność oraz elastyczność oferty dostosowanej do potrzeb lokalnych klientów. Banki nie godzą się być „okienkami” banku zrzeszającego. Natomiast ,usamodzielnienie” się poza zrzeszeniem banków, które mają kapitały własne powyżej $5 \mathrm{mln}$ euro, byłoby niekorzystne dla rozwoju całego sektora i niosło wiele zagrożeń dla samych zainteresowanych BS.

Najprawdopodobniej dalszy rozwój sektora będzie realizowany na podstawie modelu IPS, przy czym nie można wykluczyć wariantu zrzeszenia zintegrowanego, za którym opowiada się część przedstawicieli środowiska bankowości spółdzielczej. Ostateczne rozwiązania w dużej mierze będą uzależnione od zapisów ustawy o bankach spółdzielczych, ich zrzeszaniu się i bankach zrzeszających, nad nowelizacją której trwają intensywne prace od 2014 roku.

IPS ma swoje niewątpliwe plusy (rys. 1), ale wiąże się z kosztami tworzenia samej instytucji IPS (spółka prawa handlowego), systemu zarządzania ryzykiem i kontroli wewnętrznej oraz kosztami zabezpieczenia funduszu płynnościowego i gwarancyjnego, co wynika z konieczności wzajemnego gwarantowania zobowiązań przez członków systemu. $Z$ tym związane jest zagrożenie nadużywania gwarancji oferowanych $w$ ramach systemu przez niektórych jego uczestników poprzez podwyższanie ryzyka i przenoszenie jego skutków na pozostałych uczestników (moral hazard). Takiego zagrożenia nie można wykluczyć, mimo wdrożenia pewnych indywidualnych instrumentów oddziaływania na członków systemu przez jego władze (program naprawczy, ustanowienie komisarycznego zarządu).

W porównaniu do IPS, zrzeszenie zintegrowane cechuje mniejsza ingerencja w stosunki cywilnoprawne między uczestnikami systemu, a także mniejszy stopień szczegółowości, pozostawiający stronom umowy zrzeszenia większą niezależność (swobodę w kształtowaniu swoich praw i obowiązków). Członkowie zrzeszenia będą mogli lokować środki w banku zrzeszającym na dotychczasowych warunkach, jednak umożliwiających zaklasyfikowanie ich przez BZ jako środki o obniżonym współczynniku odpływu. Odpowiedzialność członków zrzeszenia będzie ograniczona na zasadach określonych w umowie. 


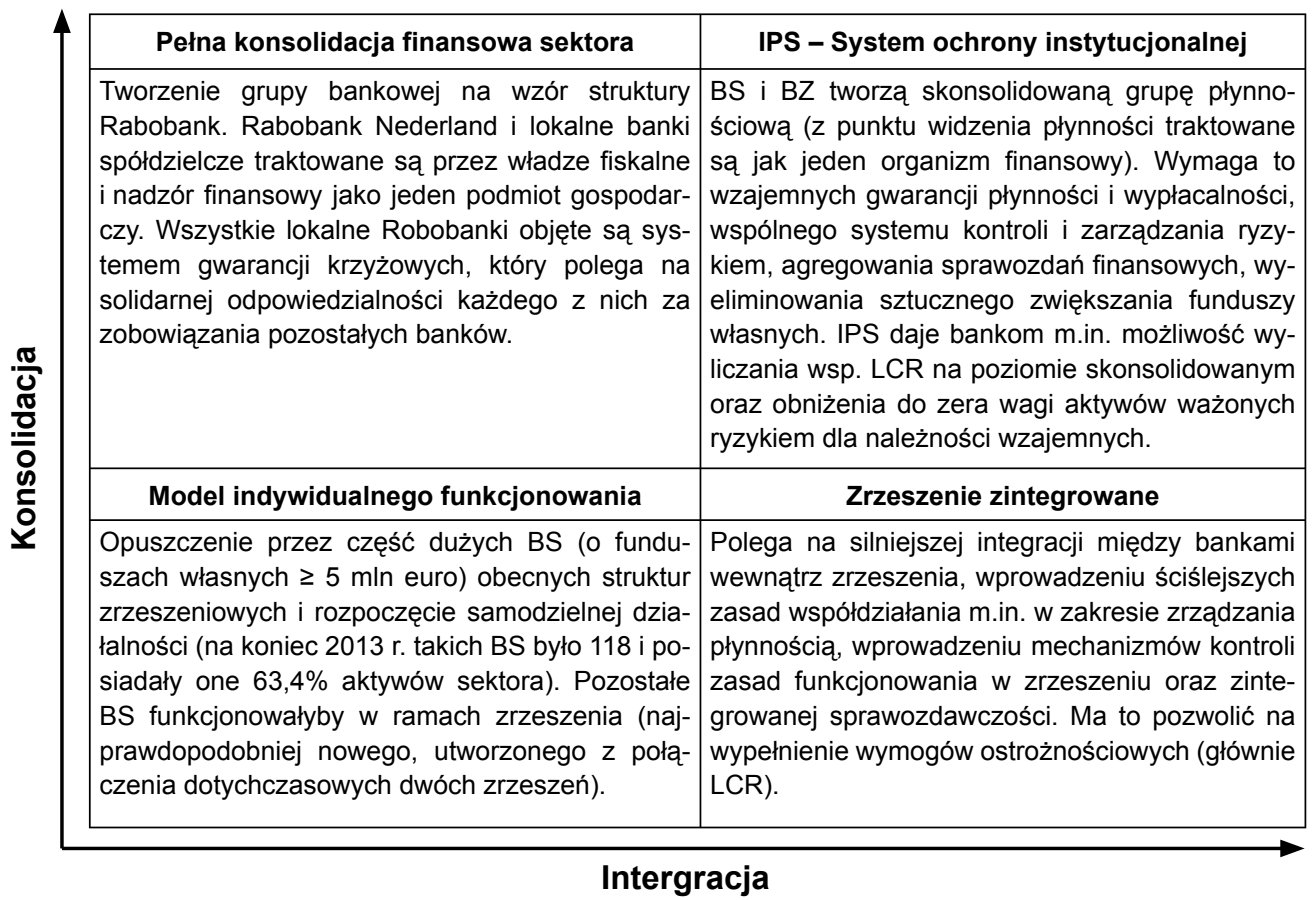

Rysunek 3

Potencjalne modele organizacyjno-biznesowe spółdzielczego sektora bankowego

Źródło: Opracowanie własne na podstawie [Alińska 2012, s. 51-60].

Ponadto uzyskanie pomocy z funduszu pomocowego będzie uzależnione od spełnienia właściwych przesłanek, w tym przyjęcia i realizacji programu naprawczego. Członkowie zrzeszenia zintegrowanego będą jednak zobowiązani do spełnienia normy LCR na poziomie indywidualnym, co tym samym niesie za sobą więcej zagrożeń w kontekście spójności zrzeszenia i wypełniania wymogów CRD IV/CRR.

\section{Podsumowanie}

Procesy konsolidacyjne realizowane na przełomie lat 1990-2000 pod presja wymogów regulacyjnych UE przyniosły wiele pozytywnych efektów w zakresie poprawy potencjału ekonomicznego i efektywności finansowej sektora BS. Jednakże po kilku latach względnie wysokiej efektywności ekonomicznej i powolnego zwiększania udziału sektora bankowości spółdzielczej na rynku bankowym ujawniło się wiele symptomów wskazujących na wyczerpanie się potencjału roz- 
wojowego dotychczasowego modelu organizacyjnego i biznesowego bankowości spółdzielczej. Obecnie funkcjonujące zrzeszenia nie sprawdzają się, a cały sektor nie wykorzystuje efektu synergii. Konieczność zmian wynika z wewnętrznej sytuacji sektora oraz presji otoczenia rynkowego. Nowe regulacje bankowe UE (zwłaszcza pakiet CRD IV/CRR) będą jedynie katalizatorem przyśpieszającym zmiany i powinny być traktowane jako szansa, a nie jedynie zagrożenie dla funkcjonowania sektora bankowości spółdzielczej.

Aktywacja potencjału rozwojowego bankowości spółdzielczej w Polsce wymaga wyboru określonej formy integracji, a być może także konsolidacji niektórych obszarów bankowości w obrębie zrzeszeń. Wpłynie to na przyszły kształt sektora bankowości spółdzielczej, a także na stopień niezależności banków spółdzielczych. Kluczowe jest to, aby nowy model biznesowy pozwalał na wykorzystanie atutów BS jako banków lokalnych, usuwając jednocześnie dotychczasowe słabości sektora i łagodząc zagrożenia rynkowe i regulacyjne. W szczególności istnieje potrzeba wzmocnienia integracji organizacyjnej i finansowej BS z bankami zrzeszającymi oraz lepszego wykorzystania banku zrzeszającego jako jednostki koordynującej i usługowej względem banków spółdzielczych.

\section{Literatura}

ALIŃSKA A., 2012: W poszukiwaniu docelowego modelu funkcjonalno-organizacyjnego bankowości spółdzielczej w Polsce, Zesz. Nauk. WSB w Poznaniu nr 45,51-60.

BAŃKA J., 2013: Stosowanie zasady proporcjonalności, VI Forum Liderów Banków Spółdzielczych, ZBP, Warszawa.

DUNAJ B. 1996: Słownik współczesnego języka polskiego, Wilga, Warszawa.

FRĄCKOWIAK W. (red.), 2009: Fuzje i przejęcia przedsiębiorstw, PWE, Warszawa.

KNF, 2014: Informacja o sytuacji banków spółdzielczych i zrzeszajacych w 2013 r., UKNF, Warszawa.

KOT-ZACHARUK A., 2011: Przekształcenia w polskiej bankowości spółdzielczej wedtug opinii zarzqdzajacych bankami spółdzielczymi, Ekonomika i Organizacja Gospodarki Żywnościowej nr 88, 267-278.

KOZAK S., 2013: Consolidation of the banking sector in Poland in 1989-2013 in comparison with the structural changes of the banking sector in the USA and the EU, NBP Working Paper nr 166.

KRACIUK J., 2006: Procesy konsolidacji w polskim sektorze bankowym, Problemy Rolnictwa Światowego, t. 15, 282-292.

MIELNIK M., SZAMBELAŃCZYK J., 2006: Ocena efektywności banków spółdzielczych $w$ Polsce $w$ latach 1997-2003 (dla czterech celów działalności), Bezpieczny Bank nr 1(30), 3-28.

PRUSKI J., 2013: Model biznesowy banków spółdzielczych na tle nowych wymogów regulacyjnych, VI Forum Liderów Banków Spółdzielczych, ZBP, Warszawa. 
PRUSKI J. 2012: Uwarunkowania rozwoju banków spótdzielczych, V Forum Liderów Banków Spółdzielczych, ZBP, Warszawa.

ROSA A. 2012: Konsolidacja sektora bankowości spółdzielczej w Polsce, Finanse, Rynki Finansowe, Ubezpieczenia nr 51, ZN USz 690, 831-839.

ROUBINI N., MIHM S., 2011: Ekonomia kryzysu, Oficyna Wolters Kluwer, Warszawa.

SABLIK S., 2004: Globalizacja konkurencji między instytucjami finansowymi, Zesz. Nauk. PTE nr 2, 129-150, Kraków.

\section{Abstrakt}

W opracowaniu dokonano analizy procesów konsolidacyjnych i integracyjnych w sektorze bankowości spółdzielczej w Polsce w latach 1993-2013. Określono także przesłanki determinujące konieczność dalszych przekształceń sektora oraz rolę, jaką w kształtowaniu nowego modelu organizacyjnego i biznesowego bankowości spółdzielczej w Polsce mogą odegrać procesy konsolidacji i integracji.

Słowa kluczowe: banki spółdzielcze, konsolidacja w sektorze bankowym, integracja sektora bankowego

\section{Processes of integration and consolidation of the cooperative banking sector in Poland}

\section{Abstract}

The study identified the processes of consolidation and integration in the cooperative banking sector in Poland in 1993-2013. The conditions that determine the necessity of further transformation the sector were presented, as well as the role of consolidation and integration processes in the formation of a new organizational and business model of cooperative banking sector in Poland.

Key words: cooperative banks, consolidation in the banking sector, the integration of the banking sector 